\title{
MEDIA NOSTALGIA IN CONTEMPORARY HUNGARIAN POP MUSIC
}

\author{
ANNA KESZEG \\ University of Debrecen, \\ Department of Communication and Media Studies ${ }^{1}$ \\ annakeszeg@gmail.com
}

\begin{abstract}
My paper focuses on the importance of nostalgia in contemporary Hungarian pop music. Based on the content analysis of the songs of two bands, Wellhello and The Biebers, it argues that late eighties and nineties nostalgia is a mainstream feeling amongst Hungarian youth. After a short description of the media nostalgia phenomenon, I claim that there are three major types of nostalgic content in contemporary Hungarian music industry (folk, socialist and transition period heritage), and the research presents the characteristics of the third. The findings of the research are integrated into the results of recent works on the current trends of media nostalgia.
\end{abstract}

Keywords: media nostalgia, eighties and nineties nostalgia, popular music, nostalgia boom, restorative nostalgia, reflective nostalgia, irony

In recent years a large amount of nostalgic content appeared in our media-saturated universes: television shows inspired by different periods of the past, memories from our childhood brought back by our social media timelines, political campaigns emphasizing a past greatness, clothing and design cultures focusing on retro effects, YouTube channels reviewing contents from their founders' past, rebranded products from the Golden Age of consumerism are just some examples of our fascination with what we left behind. As Katharina Niemeyer puts it, the nostalgia boom is shocking because of its technology-articulated presence: "But who would have thought, given the 1990s' imagining of a future filled with technology, that the beginning of the new century would in fact be marked by an increase in expressions of nostalgia, and nostalgic objects, media content and styles?" (Niemeyer 2014. 1.)

We do not need to be trend analysts of the contemporary media world to notice that our present is full of visual and textual references to the recent or distant past and that the longing for the past is one of the basic feelings for the post-truth-era's emotional communities. When we go to a Speedy Ortiz, a Superheaven or a White Lung concert, or we watch their music videos, when we are buying or admiring Vetements' clothes, when we binge-watch Stranger Things as we are waiting for Twin Peaks to restart, when we take analogue photos instead of digital ones, 
when we use the Sierra and Nashville Instagram filters or when we take a walk in the $7^{\text {th }}$ district of Budapest, we are in the middle of those phenomena. At the same time there is a whole marketing industry built on nostalgic attitudes: pubs designed like places in the fifties, hipster furniture stores with references to the material culture of different epochs and social classes, a whole clothing industry built on systematically returning trends of the twenties, thirties etc. are just a few amongst a wide range of examples. Social media sites also contribute to the nostalgia wave: each morning old memories pop-up automatically on our Facebook page, at the end of December our annual video arrives to generate the nostalgia on-the-go, and there is Instagram, considered to be a whole application inspired by nostalgia. On YouTube it is easy to spot many media-influencers whose profile is about their founders' desire to revivify their cultural memories. The vogue for nostalgic television series started in 2007 with Mad Men and became mainstream since with examples like Masters of Sex, Broadwalk Empire, etc., and the sequels to the beloved series of the seventies and the eighties, like Dallas, Hélène et les Garçons, Gilmore Girls, etc. The nostalgia wave also reached the film industry: in 2012 Martin Scorsese's Hugo, a movie about the history of movie-making received the award of the Academy of Motion Pictures Arts and Sciences, and other awards were received by the black and white musical The Artist, and for LaLaLand, a Hollywood-nostalgic musical, both still in the same year. The nostalgic behaviour in material culture crystallized around the keywords retro, vintage and hipster. All those phenomena are referred to as "media nostalgia".

I argue that the wave of media nostalgia also infiltrated the Hungarian pop music scene in the last decade. A nostalgic trend invited musicians to rework the visual and musical heritage of the eighties and the nineties. In Hungary in the 2010s two music bands with late eighties and early nineties nostalgia messages were launched: Wellhello, founded in 2014 by Tomi Fluor, a rapper known for his ironically mainstream texts and Diaz, a widely recognized songwriter, and The Biebers, founded in 2012 by Péter Puskás, a former winner of the talent show Megasztár. ${ }^{2}$ The two bands have a similar target group (digital generation from urban areas of Hungary with a middle class background) and rework the same tradition of Hungarian pop music prevalent during the childhood of the singers and of the target group. Even though Wellhello is a group with a much larger audience than The Biebers, ${ }^{3}$ by picking those two bands I wanted to emphasise how the current nostalgia discourse works on multiple levels. I equally have to point out that a sentiment of collective belonging motivates the ironic yet bittersweet longing for the past of their songs and music videos. But while the nineties was an authentic experience for the singers, the younger members of the target group are learning and re-learning that heritage via the evocative songs. Nostalgia possesses the power to become a cross-generational meeting point. 
This paper analyses the forms of nostalgia present in the songs and music videos of the above mentioned two bands. In order to differentiate between several forms of nostalgia I have to make a short description of other nostalgia phenomena in Hungarian pop music and to present some sub-genres of nostalgic attitudes in a concise literature review. My hypothesis is the following: the eighties and nineties nostalgia in Hungarian popular music is an ironic and consumerist attitude in contrast with the socialist era's more ideological and politically designed pop music or folk music nostalgia.

\section{Nostalgia-phenomena in Hungarian Music Industry}

I claim that in contemporary Hungarian cultural industries there are three major forms of nostalgic attitudes regarding the content to remember: folk nostalgia, socialist nostalgia and transition period nostalgia. Firstly, there is the revival of the folk tradition which is highly supported by contemporary official political ideology. Secondly, there is a certain type of Hungarian original programming nostalgia represented by the M3 channel of state media and its retro broadcasting policy. Thirdly, there are the above mentioned contemporary bands reworking contemporary tendencies in youth cultures who explore the popular music of their childhood from a consumerist and non-ideological perspective. In order to distinguish the particularities of the third one, I have to make a short description of the other two.

Concerning the first form of nostalgic content, a special kind of Hungarian original talent show must be mentioned, one inspired by former Hungarian content production. In 2012 the Duna TV channel (declared as the main national channel in 2015) launched a folk music-based talent show co-hosted by the House of Traditions named The Peacock had Risen (Fölszállott a páva) as a sequel to the show Fly peacock! (Röpülj páva!) presented between 1969 and 1981. It is a very spectacular, visually accurate and immersive presentation of Hungarian folk traditions in the spirit of Guy Debord's concentrated spectacle. ${ }^{4}$ That show is only one among the many manifestations of a very important official cultural trend which explores and increases the presence of Hungarian popular heritage in everyday cultural consumption and amongst contemporary commodities. A wide range of folk song and dance festivals, and ateliers dedicated to popular craftsmanship can be mentioned in this regard. My analysis cannot develop this subject here, yet, the spectacular representation of that national heritage is a very exciting subject. $^{5}$

As for the second type of nostalgic content, Ferenc Hammer provides an analysis of the manifestation of socialist nostalgia on the M3 - a thematic state television channel devoted solely to retro programming. Hammer argues that during 
Hungarian socialism popular music was a double faceted phenomenon: on the one hand there were musicians whose works "crossed lines defined by cultural policies of the Party (Hammer 2017)," and on the other hand more popular bands existed with a less resistant or subversive message who became agents of the official pop music scene. He notices a huge discrepancy in the representation of those two: the academic discourse preferred to analyse the line-crossing and subversive bands and musicians, while the other aspect of musical production was forgotten or received little scientific attention. The fact of that difference is shocking because of the mass effect that those popular bands had and still have on Hungarian social classes with the potential to generate significant cultural consumption. This is exactly the reason why contemporary Hungarian state broadcasting companies are systematically circulating the songs and music videos of the well-known and less subversive bands. He points out equally that the public appearances of a band like Neoton Família stay the same today as during their Golden Age: they accept to be objectified by local or national politicians while the songs they sing remain the same (cf. the title of Hammer's paper: The Songs Remain the Same). ${ }^{6}$

The third form of nostalgic content has a less direct connection with state ideology, concerns various media contents of the transition period, and it is more integrated into Hungarian youth's consumerist attitudes. This is what I am going to develop in the following lines after a concise presentation of literature on media nostalgia.

\section{Registers of the Memory Boom. Nostalgia and trauma, strategy and tactic, restorative and reflective nostalgia}

In spite of the importance and penetration of nostalgic phenomena, media nostalgia is a relatively new research area in media and memory studies, moreover, a critical attitude characterised the first works dealing with it. The research on memory has occupied a very prominent place in the social sciences of the last fifty years giving birth to concepts like collective memory, memorialization, cultural memory, or the politics of memory. However, there are some changes recently in the operation of the collective memory due to the fact that in the last few years new media surfaces have created a number of new phenomena which lead to the formation and re-articulation of memory communities.

The notion of "media nostalgia" is connected to two major issues due to the fact that the term itself is a complex compound with two distinct layers. On the one hand, there is nostalgia closely linked to the term of memory and on the other the term media. By definition, nostalgia denotes an emotional relationship to the past, associating personal happiness to a past segment of time or space. The word comes from the Greek and it already consists of two parts: nostos meaning return 
home, algie meaning longing, and it was coined in the $17^{\text {th }}$ century to describe a disease common among the mercenary soldiers of Switzerland of the time (Niemeyer 2014. 8). The term became an important subtype of melancholy and had a great career during the Romantic period. It can be seen, therefore, that nostalgia is the main feeling of the modernity. And as it concerns the term media, instead of summarising the wide literature of the field, let me only highlight that it is a word for various platforms, channels and environments of content expression. Media nostalgia in this regard represents those forms of nostalgia ("a liminal, ambiguous phenomenon") "that migrate[s] into deep emotional and psychological structures as well as into larger cultural, social economic and political ones" (Niemeyer 2014. 6). The definition refers at the same time to the innumerable cases of media nostalgia and to the scientific approach to deal with it: "it would be nowadays overly simplistic to reduce nostalgia to the concept of a unique regressive, embellished social phenomenon of popular culture, historical amnesia or consumer world. Instead, nostalgia has to be understood in the larger critical context of historical, political, economic and aesthetic considerations" (Niemeyer 2014. 6).

This is why media nostalgia must be connected with the operational logics of nostalgic communities. The feelings of a lost perfection and Golden Age connect many social structures of the post-truth era, nostalgia being one of the most important sentiments connecting people, and one of the main contemporary lifestyle patterns. From here on many of the recent works on nostalgia focus on its consumerism and were built on its critical description. Svetlana Boym in her 2001 work The Future of Nostalgia calls hypochondria the contemporary form of nostalgia (Boym 2001) and in the same way Gary Cross in his more recent Consumed Nostalgia wrote about the nostalgic novelty cult of rapid capitalism (Cross 2014). That collective feeling present in visual and material forms appears as a simulacrum of the past, the Golden Age, the idealized other, and suggests that the object of our desires is not in front of us but behind us. That is why our modern applications on the smartphones are inspired by offline forms, a design strategy called skeuomorphism: with this technique the signs of the perfect past can stay with us in our imperfect present.

Another aspect of nostalgia is its connexion with irony and simulation. For the first idea, I can quote Linda Hutcheon's Irony, Nostalgia and the Postmodern (Hutcheon 1998) where she points out that while for her postmodern times were rather ironic than nostalgic for a long time, nostalgic nature of postmodern is a given. In addition to Hutcheon, I could list several authors from Baudrillard to Frederic Jameson who argued that contemporary culture is nothing else but a nostalgic simulation of the past (Baudrillard 1998, Jameson 1991). Jameson pointed out how the present was born in the spirit of its own nostalgia. Thus a positive definition of contemporary nostalgia emerges, unrelated to melancholia 
and disease: "a pleasure-seeking yearning for former times that we have not, in fact, lived" (Niemeyer 2014. 10).

Additionally, it is important to realise that nostalgia has various forms. Many texts on media nostalgia summarise that this feeling is both the symptom of progress and the symptom of crisis. In her above mentioned work Svetlana Boym shows how the moderns invented nostalgia as a framework for their relation to the present (Boym 2001. 19-33.) and Baudrillard also argues that new communication technologies activate nostalgia for the real (Baudrillard 1994. 35-45). In this paper I will not bring empirical arguments to the causes of the nostalgia trend in Hungarian pop music but I have to point out that there are important differences between Eastern and Western forms of longing for the past. The socio-cultural, political and economic differences between those worlds imply radically different content for the objectification of the past. While in the United States, and in the United Kingdom the economic crisis accentuates the financial stability of the past and touches the whole society, ${ }^{7}$ in the different forms of nostalgy or Soviet chic there is no or very little reference to the economic past and the longing for it has a predominantly visual or cultural aspect. ${ }^{8}$ For the same reason, decade-based nostalgia is and will be a middle-class youth phenomenon in Hungary and it is less widespread among poorer social classes. Not to mention the fact that recent Hungarian nostalgia is less conscious about its socialist content than the per definitionem nostalgy of the Germans for the former GDR who built a serious nostalgia industry and museumificated the GDR of the late eighties.

Furthermore, it is also important to notice that Western European research on the nostalgia-politics of nineties music pointed out that dance music was the most important component of that heritage based on a distinction between early underground parties and mainstream decade parties (van Der Hoeven 2012), the popular musical genre of the epoch was pop music, the electro music scene being still 'underground' and hard-core at the time (Kálai 2017).

All this begs the next question: how did the eighties nostalgia become the workplace of the middle-class youth, what are the tools used to identify the group with the media content of their childhood? In order to demonstrate the middle-class rooted particularity of Hungarian nostalgic pop music, a distinction between nostalgia as strategy and nostalgia as tactic must be introduced in the sense that Michel de Certeau gave to those words: nostalgia as tactic is an active and creative appropriation, while nostalgia as strategy is a passive and imposed rememoration of the past (De Certeau 1984, xix). Here I will develop the claim that The Biebers and Wellhello use nostalgia as strategy in contrast with contemporary cultural politics using the longing for the past as tactic in the case of politically controlled state media (Hammer 2017). Of equal importance is Boym's thesis about the two major forms of nostalgia. The first type is the restorative nostalgia which focuses on nostos and "attempts a transhistorical reconstruction of the lost 
home" and treats itself as truth and tradition. The second type is reflective nostalgia which accentuates algia, the longing itself "and delays the homecoming wistfully, ironically, desperately" and "does not shy away from the contradictions of modernity" (Boym 2001 14). And from here I can proceed to the analysis of the lyrics and the music videos' visual features.

\section{Exactly now - twenty years ago. Nostalgia in texts and music videos}

In this synthesis I intend not only to present some of the main features of contemporary media nostalgia theories but as an illustration also try to put those findings in the context of some recent changes of Hungarian Pop Music. As a result of the content analysis of the videos and the lyrics of the above mentioned bands we'll be able to show how the nostalgia and the objectification of the past works in retro aesthetics. The textual and visual document analysis is inspired by Appadurai's affirmation that: "Thus, even though from a theoretical point of view human actors encode things with significance, from a methodological point of view it is the things-in-motion that illuminate their human and social context." (Appadurai 1988. 5.) My interest is to show the texts-in-motion: the different forms and articulations of nostalgia in the songs and music videos.

As a methodology I created a content analysis structured around three codes: the presence of textual references to the past in the lyrics with or without nostalgic content, the presence of visual references to the past with or without nostalgic effect and finally the presence of direct references to previous media contents (identifiable pop songs, TV shows, video games, commercials, etc.). As references to the past I counted every reference to memories, past events or former states of mind regardless to the tonality of expression. Nostalgic effect was present all the time when the singer expressed regret regarding the past nature of the remembered activities. Correspondingly, visual references to the past were identified in typography, the use of colours, visual forms, screening effects, clothing, interior design. As for all research dealing with visual content analysis, I can argue that despite the quantitative nature of data gathered, the decision whether a reference to a past visuality is nostalgic or not implies a qualitative procedure. ${ }^{9}$ Here I considered that a visual reference to the past was nostalgic if the images made it clear that there is a present from where those past images are evoked, if the past tense of the images was emphasized. As for the third code the major problem was the difficulty of identifying all the very vague references within the texts - in some cases in the comments and descriptions of the videos, intertextual connections helped this identification. In most of the cases a closer look at the music videos and lyrics made it clear that there is no specific media content quoted, but a general and evoc- 
ative reference to the same kind of products characterised the content production. Surprisingly, the analysis makes no reference to the music even though the songs of the two bands are full off late eighties-early nineties sound effects and musical style, and the used instruments are also similar to those of the nineties, but content analysis is not equipped with tools to identify such similarities.

The findings of my research are summarized in the following data (for a detailed presentation cf. Appendix 1.). Amongst the fourteen songs of Wellhello (seven music videos, and seven lyric videos) textual references to the past are present in 12 songs and visual effects to the past are present in all the videos. The seven lyric videos were built on the same model: an early nineties electric design reminiscent of the form of the web with lightened typos characterized the visual presentation of all songs. That visual was inspired by television show intros of the late eighties-early nineties of TV shows like Szegasztok, Szuperbola, A Hét, etc. ${ }^{10}$ Amongst music videos one was entirely inspired by a Hungarian television series of the same period (Rakpart) with the ironic casting of a well-known Hungarian radio voice for the introduction of the song. The voice is that of Péter Korbuly who read all the movie titles in Hungarian state media during socialism and became the best-known voice among Hungarian media consumers. ${ }^{11}$ The music video of apuveddmeg on the contrary imitates the visuality of 8 bit video games: that song is the first person discourse of a New Rich kid speaking to his father about his will to buy the whole town and navigate in it by an automatic car and showing to everyone how much money they have. For that textually non-nostalgic lyrics there is that video game aspect with the very characteristic pixelate image of a car stepping over obstacles and amassing money on the road. The contrast between the contemporary text and the past visual content has a slight irony which leads to nostalgia: we wish things were so simple as in the times when we played those games and fantasized about buying the whole city. Another sign of the systematic reworking of popular musical heritage is the fact that two of the songs from 2016 are directly inspired by former Hungarian hits (Fiúk ölébe lányok - a song of the mainstream rock band Tankcsapda from 1999, Balatoni nyár - a song of the band KFT from 1986), and another has a direct reference in the title to the Back to the future-universe (Vissza a jövöbe). Further evidence supporting the nostalgic visual consciousness of Wellhello is their webshop, which entertains a conspicuous MS-DOS design (cf. Appendix 2.).

The data revealed by my study proves that nostalgia is present with a similar frequency but in a completely different form in the songs of The Biebers. While expression of nostalgia on a textual level regularly occurs in those songs (in 25 out of a total of 35 songs), the visual references are less common and there are no direct quotations from previous media contents. The visual effects are recognizably inspired by the nineties, but it is impossible to indicate the concrete media texts referenced by the music videos. However, the sentiment of nostalgia is at the basis of the two albums: the sentiment of yearning for the past appears in the 
present and it is connected to good experiences which began to metamorphose in their own past as they are coming to life. That feeling is expressed in songs like Sorry, Summer Love Ghost, A Part, etc. The references to the nineties are not only more vague but also more international, less mainstream and more alternative with funky influences: the second album of The Biebers has an almost David Lynch-like interior as set design which appears in all the lyric videos of the album. An evident example of visual nostalgia is the music video of Rhythm of Joy, where the face of the singer is shown in front of a neon pink background and suddenly that image is framed by the screen of a smartphone indicating that the images are from a bygone time.

A short list of titles with reference to past, memory and nostalgia also proves the important role of a sentiment of past in that musical tradition: Wellhello: Sokszor volt már így (It has been the same so many times before), Késö már (It's too late), Emlékszem Sopronban (I remember in Sopron), Vissza a jövöbe (Back to the future); The Biebers: Summer love ghost, Memories, Pont most (Exactly now), Régi dal (Old song).

On the basis of the evidence cited above, it seems fair to suggest that nostalgia as a strategy characterises the two bands, in a more restorative and less reflective way for Wellhello, and a more reflective and less restorative way for The Biebers. On these grounds, it can be argued that nineties consumerist nostalgia in those songs is reflective in both cases: there is no truth and tradition in either case, even though the restoration of the past is more evident for Wellhello than for The Biebers. Moreover, nostalgic feeling is the main feature of both bands' content production. Further research in this area has to focus on the contribution of irony to the construction of these retro media universes.

\section{References}

Appadurai, Arjun, 1988. Introduction: Commodities and the Politics of Value. In Appadurai, Arjun, ed. The Social Life of Things, Cambridge: Cambridge University Press.

Baudrillard, Jean, 1994. Simulacra and Simulation. University of Michigan Press.

Berdahl, Daphne, 1999. "(N)Ostalgie" for the present: Memory, longing, and East German things. Ethnos 64(2), 192 - 211.

Boym, Svetlana, 2001. The Future of Nostalgia. Basic Books.

Certeau, Michel de, 1984. The Practice of Everyday Life. Berkeley: University of California Press.

Cross, Gary, 2014. Consumed Nostalgia. Memory in the Age of Fast Capitalism. New York: Columbia University Press.

Debord, Guy, 1967. La Société du Spectacle. Paris: Buchet-Castel.

Earle, Samuel, 2017. The Politics of Nostalgia. Jacobingmag 1. 20. https://www.jacobinmag. com/2017/01/donald-trump-inauguration-nationalism/.

Feischmidt, Margit - Pulay, Gergő, 2014. Élmény és ideológia a nacionalista popkultúrában. In Feischmidt, Margit ed. Nemzet a mindennapokban. Az újnacionalizmus populáris kultúrája. Budapest: L'Harmattan, 249-290. 
Hammer, Ferenc, 2017. The Songs Remain the Same. Structures of Cultural Politics of Retro in Hungarian Pop Music. In Barna, Emília - Tófalvy, Tamás ed. Made in Hungary, Studies in Popular Music. New York: Routledge, 45-67.

Hoeven, A. van der, 2012. Remembering the popular music of the 1990s: dance music and the cultural meanings of decade-based nostalgia. International Journal of Heritage Studies 20(3), 310-330.

Hutcheon,Linda, 1998. Irony, Nostalgia, and the Postmodern. http://www.library.utoronto.ca/utel/ criticism/hutchinp.html

Jameson, Frederic, 1991. Postmodernism, or the Cultural Logic of Late Capitalism. Durham, NC: Duke University Press.

Kálai, Sándor, 2017 "This kind of music informs you about the present state of the world" DJ Palotai's position within the contemporary Hungarian underground culture. In Barna, Emília - Tófalvy, Tamás ed. Made in Hungary, Studies in Popular Music. New York: Routledge, 123131.

Niemeyer, Katharina, 2014. Introduction: Media and Nostalgia. In Niemeyer, Katharina, ed. Media and Nostalgia. Yearning for the Past, Present and Future. New York: Palgrave Macmillan, $1-23$.

Rose, Gillian, 2007. Content Analysis. Counting what you (think you) see. In Rose, Gillian, ed. Visual Methodologies. Introduction to the Interpretation of Visual Materials. London: Sage Publications, 59-74.

Szemere, Anna, 2001. Up from the Underground. The Culture of Rock Music University Park: The Pennsylvania Sate University Press.

\section{Notes}

1 annakeszeg@gmail.com

2 Megasztár is a Hungarian original talent show of the TV2 Channel debuted in 2003. Puskás was a finalist of the third edition in 2005-2006.

3 Wellhello was the protagonist of many spectacular shows (the Pilvaker show sponsored by Red Bull organized with the occasion of the national day of 15 th March), they are the creators of the hymn of several music festivals and in 2016 a movie inspired by their music came out with the title \#sohavégetnemérös (\#neverending).

4 Guy Debord makes a difference between the concentrated and the diffuse spectacle in his influential work The society of the spectacle. The diffuse spectacle is characteristic to the consumerist capitalism where the different commodities are present in a spectacular abundance. The concentrated spectacle characterises the Eastern Bloc or advanced capitalist countries in times of crisis and it presents cultural values approved by the bureaucratic class and a powerful political leader (Debord 1967). He introduced later a third form to this distinction, the integrated spectacle, but as it is not crucial to my argument, I am not following up on that idea here.

5 Cf. Feischmidt - Play 2014. The whole book focuses on research on that topic from the perspective of nationalist content in everyday commodities and cultural behavior.

6 The heritage of rock music is in a blurred position: as it is a very complex and more documented field, I refer the reader to the important works of Anna Szemere on the subject: Szemere 2001.

7 Earle 2017. While the arguments and diagnosis of Earle are broadly acknowledged, I quote his text because of its Hungarian reference: "On one level, such nostalgia is nothing new. Mythical memory has always been a pillar of nations, and rose-tinted recollection, the lament for lost times, is as old as memory itself. Asked how their day was, a proverbial Hungarian put it perfectly: »Oh, you know, things are about average. Not as good as yesterday, better than tomorrow. «" 
8 For one of the first scientific description of the nostalgie cf: Berdahl 1999.

9 On the methodologically problematic nature of visual content analysis cf. Rose 2007.

10 For those generics cf. the following Youtube-videos: A Magyar Televízió Története 2-3-4. (1978-1988, 1989-1991, 1991-1994). History of Hungarian Television 2-3-4. https:// www.youtube.com/watch?v=eX5f2bM6i-A, $\quad$ https://www.youtube.com/watch?v=6y Yohm3jP70, https://www.youtube.com/watch?v=Bg9NGAIddSM.

11 There is a reference in the description of the Youtube-video of Rakpart's music video to another Youtube-video presenting Péter Korbuly, the face behind the famous voice: https://www.youtube.com/watch? $=\mathrm{jx} 4 \mathrm{KORWqENI}$ 